\title{
PROSES PENDAFTARAN PERALIHAN HAK ATAS TANAH DALAM PERSPEKTIF KEPASTIAN HUKUM
}

\author{
Jolanda Marhel \\ Program Studi Ilmu Hukum, Universitas Nusa Cendana \\ marhel.jolanda@yahoo.com
}

\begin{abstract}
Transitional registration land rights pursuant to article 103 paragraph (7) at least 7 but article 103 paragraph (7) open space that although more than (7) the office perntahan are obliged to accept therefore problems in writing this how the implementation of article 103 paragraph (1) and paragraph (7) the minister agrarian country number 3 years 1997 in the process of transition land rights at the district land office kupang? And the fate of the implementation of article 103 paragraph (1) and paragraph (7) the minister agrarian country number 3 years 1997 in the process of transition land rights at the district land office kupang?. The research is empirical research with the methods approach juridical empirical and approach conceptual.As for the result of research that the District Land Office Kupang in fact of being dilemma for want of rejected but PPAT also have referral law and led to the absence of certainty the law so that suggested need to revised article 107 paragraph( 7).
\end{abstract}

Keywords: Land Certificate, Registration Land Rights, Intermediate Land Rights, Legal Certainty

\begin{abstract}
Abstrak
Pendaftaran peralihan hak atas tanah menurut Pasal 103 ayat (7) paling lambat 7 namun Pasal 103 ayat (7) membuka ruang bahwa walaupun lebih dari 7 hari kantor perntahan wajib menerima oleh sebab itu permasalahan dalam penulisan ini Bagaimana implementasi Pasal 103 Ayat (1) dan Ayat (7) Peraturan Menteri Negara Agraria No. 3 Tahun 1997 dalam proses pendaftaran peralihan hak atas tanah di Kantor Pertanahan Kabupaten Kupang? Dan Bagaimana akibat hukum dari implementasi Pasal 103 Ayat (1) dan Ayat (7) Peraturan Menteri Negara Agraria No. 3 Tahun 1997 dalam proses pendaftaran peralihan hak atas tanah di Kantor Pertanahan Kabupaten Kupang?. Penelitian ini merupakan penelitian empiris dengan metode pendekatan yuridis empiris dan pendekatan konseptual. Adapun hasil penelitian bahwa Kantor Pertanahan Kabupaten Kupang dalam kenyataan menjadi dilema karena ingin menolak tetapi PPAT juga punya rujukan hukum dan berakibat pada tidak adanya kepastian hukum sehingga disarankan perlu untuk direvisi Pasal 107 ayat (7).
\end{abstract}

Kata Kunci : Akta Tanah, Pendaftaran Hak atas Tanah, Peralihan Hak Atas Tanah, Kepastian Hukum

\section{A. Pendahuluan}

1. Latar belakang Permasalahan

Kegiatan pendaftaran tanah untuk pertama kali diperuntukan bagi tanah-tanah yang belum pernah terdaftar sehingga dapat diterbitkan sertipikat hak atas tanahnya, sedangkan kegiatan pemeliharaan data pendaftaran tanah dilakukan terhadap tanah yang sudah terdaftar atau sudah bersertipikat, guna mencatat setiap perubahan-perubahan yang terjadi pada data fisik yang berupa peta atau data yuridis tanah tersebut di dalam Sertipikat sehingga data pemegang hak dapat tersaji tepat sesuai dengan kenyataan yang ada. Pendaftaran Peralihan hak atas tanah termasuk di dalam kegiatan pemeliharaan data pendaftaran karena dari setiap peralihan hak atas tanah yang terjadi akibat jual beli, 
tukar menukar, hibah, pemasukan data perusahaan dan lain-lain, dan yang dibuktikan dengan akta yang dibuat oleh PPAT atau PPAT sementara, haruslah tercatat dalam sertipikat hak atas tanah.

Kepala Kantor Pertanahan dan PPAT atau PPAT Sementara dalam melaksanakan pendaftaran peralihan hak ini merujuk pada Peraturan Pemerintah Nomor 24 Tahun 1997 dan peraturan pelaksanaannya yaitu Peraturan Menteri Negara Agraria/ Kepala Badan Pertanahan Nasional No. 3 Tahun 1997 tentang Ketentuan Pelaksanaan Peraturan Pemerintah No. 24 Tahun 1997 tentang Pendaftaran Tanah yang sampai saat ini masih berlaku (Dalam penulisan ini selanjutnya disebut dengan Permenag /KaBPN Nomo 3 Tahun 1997.). Dalam Permenag/ KaBPN No. 3 Tahun 1997 diatur prosedur pelaksanaan pendaftaran peralihan hak atas tanah yang harus dilakukan oleh pihak-pihak yang bertugas melaksanakan kegiatan pendaftaran. Akta tanah yang dibuat oleh PPAT yang dijadikan dasar dalam proses pendaftaran antara lain berupa Akta Jual Beli, Akta Tukar Menukar, Akta Hibah, Akta Pemasukan ke dalam perusahaan, Akta Pembagian Hak Bersama, Akta Pemberian Hak Tanggungan, Akta Pemberian Hak guna Bangunan Atas Tanah Hak Milik, Akta Pemberian Hak pakai Atas Tanah Hak Milik. Akta-akta tersebut dan Sertipikat Hak Atas Tanah serta dokumendokumen pelengkap lainnya wajib disampaikan ke Kantor Pertanahan agar dapat dicatat atau dicantumkan peralihan haknya dalam buku tanah, sertipikat dan daftar lainnya paling lambat 7 (tujuh) hari kerja terhitung sejak akta tersebut ditandatangani oleh PPAT atau PPAT Sementara. Hal ini diatur dalam Pasal 103 ayat (1) Permenag/KaBPN No. 3 Tahun 1997 yang menyatakan bahwa:

"PPAT wajib menyampaikan akta PPAT dan dokumen-dokumen lain yang diperlukan untuk keperluan pendaftaran peralihan hak yang bersangkutan kepada Kantor Pertanahan selambatlambatnya 7 (tujuh) hari kerja sejak ditandatanganinya Akta yang bersangkutan".
Pasal 103 ayat (1) Permenag/KaBPN No. 3 Tahun 1997 inilah menjadi pedoman dan dasar hukum bagi setiap Kantor Pertanahan dan PPAT memproses pendaftaran Akta PPAT dalam peralihan hak atas tanah, Namun pada kenyataannya terdapat berkas permohonan yang disampaikan ke Kantor Pertanahan melebihi jangka waktu yang telah ditentukan oleh Pasal 103 ayat (1) yaitu lebih dari 7 (tujuh) hari kerja. Secara kenyataan Kepala Kantor Pertanahan sendiri tidak dapat menolak semua pengajuan pendaftaran Akta PPAT yang telah lewat waktu seperti yang dimaksudkan dalam Pasal 103 ayat (1), hal ini dikarenakan Pasal 103 ayat (7) Permenag/KaBPN No. 3 Tahun 1997 yang menyatakan bahwa :

"Pendaftaran peralihan hak karena pemindahan hak yang dibuktikan dengan akta PPAT harus juga dilaksanakan oleh Kepala Kantor Pertanahan sesuai ketentuan yang berlaku walaupun penyampaian akta PPAT melewati batas waktu 7 (tujuh) hari sebagaimana yang dimaksud pada ayat (1)".

Merujuk dalam Pasal 103 ayat (7) ini maka Kantor Pertanahan wajib untuk menerima setiap pengajuan pendaftaran walaupun telah melewati batas waktu sehingga disinilah terjadi kontradiksi atau inkonsisten antara ayat (1) dan ayat (7) khususnya dalam satu pasal yaitu Pasal 103. Dalam ayat (1) menghendaki PPAT wajib melaporkan Aktanya dalam jangka waktu 7 (tujuh) hari kerja setelah ditandatangani akta tersebut, namun pada ayat (7) walaupun lewat dari 7 (tujuh) hari kerja, Kantor Pertanahan harus menerima Akta yang diajukan oleh PPAT untuk didaftarkan. Hal inilah yang menjadi dilema bagi Kantor Pertanahan dalam mengambil tindakan bagi PPAT yang terlambat mengajukan permohonan pendaftaran peralihan hak karena pemindahan hak.

Menurut Pasal 103 ini, apabila ayat (1) tidak dilaksanakan maka hal tersebut merupakan pelanggaran namun dalam ayat (7) dengan adanya keterlambatan yang 
merupakan pelanggaran, pendaftaran peralihan haknya dapat diproses. Tidak dipatuhinya Pasal 103 ayat (1) oleh pihak PPAT dianggap sebagai suatu temuan dalam pemeriksaan internal dari intitusi yang diberikan kewenangan untuk melaksanakan pendaftaran tanah ini. Pasal 103 ayat (7) membuka ruang adanya pelanggaran terhadap pelaksanaan ayat (1) secara terus menerus. Adapun gambaran yang terkait dengan implementasi Pasal 103 ayat (1) dan ayat (7) terhadap proses pendaftaran peralihan hak atas tanah yang terjadi, dapat dilihat melalui data dari Kantor Pertanahan Kabupaten Kupang, data tersebut dapat disajikan oleh calon peneliti dalam tabel di bawah ini :

\section{Tabel I \\ Jumlah Data Berkas Peralihan Hak Di Kantor Pertanahan Kabupaten Kupang}

\begin{tabular}{|l|c|c|c|c|c|c|c|}
\hline No. & Nama PPAT & \multicolumn{3}{|c|}{ Tahun 2014 } & \multicolumn{3}{c|}{ Tahun 2015 } \\
\cline { 3 - 8 } & $\begin{array}{c}<7 \\
\text { hari } \\
\text { kerja }\end{array}$ & $\begin{array}{l}7 \text { hari } \\
\text { kerja }\end{array}$ & $\begin{array}{l}>7 \text { hari } \\
\text { kerja }\end{array}$ & $\begin{array}{l}<7 \text { hari } \\
\text { kerja }\end{array}$ & $\begin{array}{l}7 \text { hari } \\
\text { kerja }\end{array}$ & $\begin{array}{l}>7 \text { Hari } \\
\text { kerja }\end{array}$ \\
\hline 1. & $\begin{array}{c}\text { LMWL } \\
\text { (Inisial) }\end{array}$ & 28 & - & 1 & 54 & - & 1 \\
\hline 2. & EDU (Inisial) & 9 & - & 48 & 85 & - & 69 \\
\hline 3. & ADJ (Inisial) & 43 & 6 & 98 & 121 & 2 & 154 \\
\hline & Jumlah & 80 & 6 & 147 & 260 & 2 & 224 \\
\hline
\end{tabular}

Berdasarkan tabel I di atas maka calon peneliti dapat menyimpulkan bahwa selama dalam kurun waktu 2 (dua)tahun terakhir ini yaitu tahun 2014 terdapat 80 berkas permohonan yang didaftarkan pada Kantor Pertanahan Kabupaten Kupang di bawah jangka waktu 7 (tujuh) hari sejak ditandatanganinya Akta peralihan hak oleh Pejabat Pembuat Akta Tanah, 6 (enam) berkas permohonan tepat waktu sesuai dengan batas waktu yang ditentukan oleh Peraturan Pemerintah, dan 147 berkas permohonan telah melampaui batas waktu yang ditentukan. Begitu pula hal yang sama terjadi pada tahun 2015, 260 berkas permohonan yang didaftarkan kurang dari 7 (tujuh) hari, 2 berkas permohonan didaftarkan tepat pada hari ke-7 sedangkan ada 224 berkas permohonan yang melampaui waktu 7 (tujuh)hari.

Jika mengacu pada Ayat (1) Pasal 103 Permenag tersebut maka untuk berkas permohonan yang berisi Akta PPAT dan dokomen kelengkapan lainnya yang diajukan lebih dari 7 (tujuh) hari sejak ditandatanganinya Akta peralihan hak oleh PPAT tidak dapat diterima lagi oleh Kantor Pertanahan /Kota, namun jika mengacu pada Pasal 103 ayat (7) maka walaupun sudah lewat waktu Kantor Pertanahan atau Kota tetap harus menerima berkasberkas tersebut. Di sinilah terjadi pertentangan ayat dalam satu pasal sehingga ketika dalam menjalankan tugasnya Kantor Pertanahan/kota tidak mempunyai suatu pegangan yang pasti sehingga terjadi polemik dalam menegakan hukum itu sendiri.

\section{Permasalahan}

1. Bagaimana implementasi Pasal 103 Ayat (1) dan Ayat (7) Peraturan Menteri Negara Agraria No. 3 Tahun 1997 dalam proses pendaftaran peralihan hak atas tanah di Kantor Pertanahan Kabupaten Kupang?

2. Bagaimana akibat hukum dari implementasi Pasal 103 Ayat (1) dan Ayat (7) Peraturan Menteri Negara Agraria No. 3 Tahun 1997 dalam proses pendaftaran peralihan hak atas tanah di Kantor Pertanahan Kabupaten Kupang?

Tujuan penelitian yaitu untuk mengetahui implementasi Pasal 103 Ayat (1) dan Ayat (7) Peraturan Menteri Negara Agraria No. 3 Tahun 1997 dalam proses pendaftaran peralihan hak atas tanah serta akibat hukum yang timbul di Kantor Pertanahan Kabupaten Kupang.

\section{Metode Penelitian}

Penelitian yang penulis lakukan ini, jika dilihat dari tipe (sifatnya) maka penelitian ini adalah penelitian yang bertipe (sifat) deskriptif "descriptive research". Kountur (Kountur Ronny, 2003) mengartikan penelitian yang bersifat deskriptif adalah penelitian 
yang hendak memberikan gambaran atau uraian atas suatu keadaan sejelas mungkin tanpa ada perlakuan terhadap objek yang diteliti. Sifat dan penelitian ini adalah deskriptif kualitatif yang bertujuan untuk menggambarkan, menginventarisir dan menganalisis teori-teori dan peraturanperaturan yang berhubungan dengan permasalahan yang diteliti seperti yang dikatakan Soejono Soekanto dalam jurnalnya Darwin Ginting (Darwin Ginting, 2011) bahwa diskriptif kualitatif adalah teknik Pengolahan data pada hakikatnya merupakan kegiatan untuk mengadakan sistematisasi terhadap bahan-bahan hukum. Sistematisasi berarti membuat klasifikasi terhadap bahan-bahan hukum tersebut untuk memudahkan pekerjaan analisis dan konstruksi. Adapun penelitian ini dilakukan di Kantor Pertanahan Kabupaten Kupang dan Kantor PPAT/Notaris Wilayah Kabupaten Kupang. Metode pendekatan yang digunakan yaitu pendekatan yuridis empiris dan pendekatan konseptual. Untuk teknik pengmpulan dilakukan dengan cara wawancara dan penelusuran terhadap bahan-bahan hukum sehingga metode yang dgunakan dalam menganilisisnya yaitu yuridis deskriptif dengan menggunakan metode deduktif yaitu data umum tentang konsepsi hukum baik berupa asas-asas hukum postulat, serta ajaran-ajaran (doktrin) dan pendapat para ahli yang dirangkai secara sistematik sebagai susunan fakta-fakta hukum untuk mengkaji tentang proses pendaftaran peralihan hak atas tanah dalam kaitannya dengan Pasal 103 ayat (1) dan Ayat (7) Peraturan Menteri Negara agraria Nomor 3 Tahun 1997 tentang Peraturan Pelaksanaan Pendaftaran Tanah.

\section{B. Hasil dan Pembahasan}

1. Implementasi Pasal 103 Ayat (1) dan Ayat (7) Peraturan Menteri Negara Agraria No. 3 Tahun 1997 dalam proses pendaftaran peralihan hak atas tanah di Kantor Pertanahan Kabupaten Kupang

Makna kata implementasi menurut hemat penulis mempunyai arti dengan kata penerapan atau bisa dalam artian dengan menjalankan suatu peraturan, sehingga dalam pembahasan ini penulis akan mencoba mambahas tentang penerapan atau dari Pasal 103 ayat (1) dan ayat (7) dari peraturan menteri Negara agraria No. 3 Tahun 1997 khsusus dalam hal proses peralihan hak atas tanah. Berdasarkan uraian ini maka salah satu bagian dari pendafataran tanah yaitu pendaftaran peralihan hak atas tanah, untuk itu maka menurut pendapatnya urip santoso (Urip Santoso, 2010) mengatakan bahwa hakhak yang dimiliki oleh pemegang meliputi hak untuk mempergunakan tanah dan/atau mengambil mafaat dari tanah, mewariskan hak tanah, memindahkan ha katas tanah, memindahkan hak atas tanah, membebani hak atas tanah dengan hak tanggungan, dan melepaskan atau menyerahkan hak atas tanah tersebut. Pendapat ini selatas dengan pendapatnya Winahyu Erwiningsih (Winahyu Erwiningsih, 2009) bahwa Sumber hak milik itu adalah hak ulayat yang menurut hukum adat adalah hukum asli bangsa Indonesia, artinya tanah milik perseorangan dilekati fungsi sosial, yang artinya tanah milik perseorangan bukan saja harus dipergunakan (atau tidak dipergunakan) tanpa merugikan orang lain, melainkan justru harus diletakkan dalam rangka pemanfaatannya untuk kesejahteraan umum.

Merujuk pada uraian singkat di atas maka PPAT wajib untuk mendaftakan akta peralihan ha katas tanahnya kepada kantos Pertanahan Kabupaten Kupang paling lambat 7 hari namun demi mewujudkan kepastian hukum. Pasal 103ayat (1) dasarnya wajib maka tidak penegecualian bagi PPAT oleh sebab itu jika merujuk pada Peraturan Pemerintah No. 24 Tahun 1997 tentang Pendaftaran Tanah khsususnya ketentuan Pasal 62 yang menegaskan :

\section{Pasal 62}

"PPAT yang dalam melaksanakan tugasnya mengabaikan ketentuanketentuan sebagaimana dimaksud dalam Pasal 38, Pasal 39 dan Pasal 40 serta ketentuan dan petunjuk yang diberikan oleh Menteri atau Pejabat yang ditunjuk dikenakan tindakan administratif berupa teguran tertulis 
sampai pem-berhentian dari jabatannya sebagai PPAT, dengan tidak mengurangi kemungkinan dituntut ganti kerugian oleh pihak-pihak yang menderita kerugian yang diakibatkan o 1 e h d i a b a i - k a n n y Ketentuanketentuan tersebut".

\section{Ketentuan Pasal 40 :}

1. Selambat-lambatnya 7 (tujuh) hari $\mathrm{k}$ e r j a s e jak t a n g g a 1 ditandatanganinya akta ang bersangkutan, PPAT wajib menyampaikan akta yang dibuatnya berikut dokumendokumen yang bersangkutan kepada Kantor Pertanahan untuk didaftar.

2. PPAT wajib menyampaikan pemberitahuan tertulis mengenai telah disampaikannya akta sebagaimana di-maksud pada ayat (1) kepada para pihak ang bersangkutan.

Inilah yang menjadi suatu polemik dalam penagakan hukum khususnya dalam hal pengimplementasi Pasal 103 ayat (1) dan ayat (7) karena antara ayat (1) dan ayat (3) menurut pendapat penulis tidak searah ata sejalan sebab disatu sisi aturannya melarang disisi lain juga membuka peluang oleh sebab itu maka menurut hemat penulis inti dari penegakan hukum yaitu adanya keselarsan seperti yang dikakatakn oleh Fance M. Watu (Fance M. Watu, 2012) bahwa inti dari penegakan hukum secara konsepsional terletak pada kegiatan menyelerasikan hubungan nilai-nilai yang terjabarkan di dalam kaidah-kaidah. Akibat dari inkonsistensi dari Pasal 103 ayat (1) dan ayat (7) ini membuat pelaku hukum khususnya Kantor Pertanahan Kabupaten Kupang menjadi sulit dalam melakukan penegakan hukum berupa penjatuhan sanksi administrasi kepada PPAT yang terlambat atau mendaftarkan akta pertanahannya lewat dari jangka waktu 7 hari. Oleh sebab itu kantor pertanahan dalam melakukan penegakan hukum berupa penjatuhan sanksi kepada PPAT hanya berupa surat penagasan dalam hal segera mendaftarkan dan teguran-teguran lisan dari Kantor Pertanahan Kabupaten Kupang saja kepada PPAT.

Sanksi-sanksi ini menurut hemat penulis sangat tidak efektif karena hal ini masih saja terulang lagi seakan PPAT tidak pernah merasa jera sebab menurut PPAT mereka juga punya dasar hukum yaitu ayat (7) dari Pasal 103. Persoalan ini kemudian menjadi temuan dari Irjen BPN RI dalam kunjungan evaluasi tentang proses pendaftaran peralihan hak atas tanah di Kantor Pertanahan Kabupaten Kupang. Menurut hasil wanwancara dengan PPAT Lusia Maria Willibrorda Liliweri (Hasil wawancara dengan PPAT Ibu Lusia Maria Willibrorda Liliweri) menyatakan bahwa :

"Kami selama ini melakukan segala sesuatu ada dasar hukumnya jika kantor pertanahan menggunakan Pasal 103 ayat (1) kami juga ada dasar hukum yaitu Pasal 103 ayat (7), dan jika terlambat pun tiak ada konsekuensi hukum bagi kami”.

Berdasarkan uraian di atas maka menurut hemat penulis dengan tidak adanya sanksi maka membuat PPAT merasa acuh tak acuh karena jika ada sanki maka sanksi dapat menjaddi daya paksa agar PPAT taat dalam penyelengaraan administrasi sebab sanksi merupakan salah satu bagian yang tidak dapat dipisahkan dalam penegakan hukum khususnya di bidang pertanahan oleh sebab itu maka perlu adanya penafsiran hukum untuk mengisi kekosongan hukum yang ada seperti yang dikatakan oleh Hwian Christianto (Hwian Christianto, 2011) bahwa Ketentuan hukum sering kali tertinggal dari perkembangan oleh sebab itu perlu adanya penafsiran hukum untuk mengisi kekosongan hukum yang ada. Pendapat ini kemudian ditegaskan juga oleh A. Sukris Samardi (A. Sukris Samardi, 2012)bahwa Penafsiran kontekstual ingin melihat hukum dalam konteks social atau dalam perspektif social bukan pada teks hukum.

2. Akibat hukum dari implementasi Pasal 103 Ayat (1) dan Ayat (7) Peraturan Menteri Negara Agraria No. 3 Tahun 1997 dalam proses pendaftaran peralihan hak atas 


\section{tanah di Kantor Pertanahan Kabupaten Kupang}

Pasal 103 ayat (1) dan ayat (7) Peraturan Menteri Negara Agraria No. 3 Tahun 1997 merupakan salah satu bentuk inskonsitensi atau dengan kata lain menurut pendapat penulis yaitu ketidakharmonisan antara ayat 1 dan ayat 7 dalam Pasal 103 tersebut. Hal ini tentu sangat berdampak penegakan hukumnya atau pengimplemnetasi pasal 103 ayat 1 dan ayat 7 karena akan membuat pelaku-pelaku hukum atau penagak hukum merasa bingung atau merasa tidak pasti dalam menjalankan hukum tersebut.

\section{Ketentuan Pasal 103 ayat (1):}

"PPAT wajib menyampaikan akta PPAT dan dokumen-dokumen lain yang diperlukan untuk keperluan pendaftaran peralihan hak yang bersangkutan kepada Kantor Pertanahan, selambat-lambatnya 7 ( t u juh ) hari kerja sejak ditandatanganinya akta yang bersangkutan".

\section{Ketentuan Pasal 103 Ayat (7):}

"Pendaftaran peralihan hak karena pemindahan hak yang dibuktikan dengan akta PPAT harus juga dilaksanakan oleh Kepala Kantor Pertanahan sesuai ketentuan yang berlaku walaupun penyampaian akta PPAT melewati batas waktu 7 (tujuh) hari sebagaimana dimaksud pada ayat (1)".

Jika kita merujuk pada Pasal 103 ayat maka PPAT wajib hukumnya harus mendaftarkan peralihan ha katas tanah paling lambat 7 hari. Makna kata wajib berarti tidak ada pilihan lain selain 7 hari tersebut dan tidak boleh lewat jangka waktu seperti yang telah ditentukan tersebut. Namun pada ayat (7) dari Pasal 103 justru membuka ruang walaupun telah lewat waktu dengan jalan memberikan kewajiban kepada kepala Kantor Pertanahan untuk tetap menerima. Hal ini merupakan suatu bentuk inkonsistensi dalam ayat 1 bertentang dengan ayat 7 sehingga kedua ayat ini jika dilihat secara sepentias tidak memiliki kekuatan apapun dalam implementasinya. Berdasarkan uraian dari tidak konsistennya atau inkonsistensi dari ayat (1) dan ayat (7) dalam Pasal 103 Peraturan Menteri Negara Agraria No. 3 Tahun 1997 dalam prakteknya tentu mengakibatkan implikasi atau dengan kata lain akibat hukum bagi Kantor Pertanahan Kabupaten Kupang dalam melakukan proses pendaftaran peralihan ha katas tanah. Akibat hukum yang sering ditemui di lapangan khususnya oleh Kantor Pertanahan Kabupaten Kupang yaitu :

1. Pegawai di Kantor Pertanahan Kabupaten Kupang menjadi dilema dalam menjalankan aturan tersebut karena ingin menegakan ayat 1 dari Pasal 103 yaitu batas waktu 7 hari namun jika PPAT terlambat mereka menggunakan alasan dengan dasar hukumnya ayat (7) dari Pasal 103.

2. Tidak adanya kepastian hukum

Dalam proses pendaftaran perlihan ha katas tanah Kantor Pertanahan Kabupaten Kupang sebagai unsur pelaksana tentu membutuhkan suatu kepastian hukum, namun dengan adanya ayat (7) dari Pasal 103 ini membuat pegawai Kantor Pertanahan Kabupaten Kupang merasa tidak ada kepastian hukum karena ingin berpatokan pada ayat (1) Pasal 103 tetapi PPAT justru mengantisipasi dengan ayat (7) Pasal 103.

Hal ini selaras dengan pandapatanya Ibu Wini Lani yang mengatakan bahwa: (Hasil wawancara dengan Ibu wini Lani)

"Kita sebagai pegawai tentu merasa kebingungan karena kita sering mengaskan menggunakan ayat (1) Pasal 103 namun yang adaPPAT sering terlambat dalam mendaftrakan pendaftaran peralihan hak atas tanah karena mereka menggunakan dasar ayat (7) Pasal 103. Jadi menurut saya lebih baik ayat (7) itu dihapus saja kalau mau menjamin adanya kepastian hukum cukup kita menggunakan dasafr hukum ayat (1) Pasal 103 saja sedangkan ayat (7) bila perlu kita ganti dengan rumusan tentang sanksi yang akan diberikan kepada PPAT jika mereka terlambat mendaftarkan perailhan hak atas tanah".

3. Pasal 103 khususnya ayat 7 lebih berpihak kepada PPAT sehingga 
persoalan yang timbul PPAT menjadi acuh tak acuh dalam melakukan pendaftaran akta peralihan hak di Kantor Pertanahan Kabupaten Kupang karena PPAT berpikir bahwa walaupun terlambat masih saja bisa diterima. Hal ini jsutru memanjakan PPAT dalam menjalankan tugas dan tanggung jawabnya sebagai Pejabat Pembuat Akta Tanah. Berdasarkan hasil wawancara dengan Kepala Kantor Pertanahan Kabupaten Kupang mengatakan bahwa : (Hasil wawancara dengan Kepala Kantor Pertanahan Kabupaten Kupang)

"Adanya inkonsitensi dari ayat (1) dan ayat (7) dari Pasal 103 ini sebenarnya suatu bentuk pelemahan bagi pegawai kantor pertanahan dalam menjalankan tugas dan tanggung jawabnya dalam memproses pendaftaran peralihan ha $\mathrm{k}$ atas tanah. Karena menurut beliau ayat (7) dari Pasal 103 ini lebih pro pada PPAT atau lebih melindungi kepentingan dari PPAT yang akibatnya semua proses dalam pendaftaran peraliohan ha katas tanah menjadi berlarut. Sehingga ini dalam pemerikasaan BPN RI menjadi temuan karena BPN RI lebih memegang tegu pada ayat (1) dari Pasal 103. Artinya menurut mereka lebih dari 7 hari maka tidak akan diproses".

Berdasarkan uraian-uraian tentang akibat hukum yang muncul di atas maka menurut pendapat penulis sudah saatnya Pasal 103 khususnya ayat (7) perlu untuk ditinjau kembali agar dapat direvisi pada waktu yang akan datang. Karena menurut hemat penulis jika ayat (7) dari Pasal 103 masih saja dipertahankan maka sudah tentu akan menjadi senjata ampuh bagi PPAT dalam mendaftarkan semua akta peralihan haknya yang sudah lewat waktu 7. Maka sudah tentu menurut hemat penulis maka ayat (1) dari Pasal 103 ini sama saja mubasir dan tidak memiliki arti apa-apa. Tentu hal ini akan menghambat penegakan hukum dalam bidang pertanahan karena subtansi hukum yang tidak konsisten oleh sebab itu, maka menurut hemat penulis perlu adanya koordinasi yang lebih lanjut tentang aturan yang akan menjadi rujukan dalam penegakan hukum dibidang pertanahan seperti yang dikatakan oleh Fenty U Puluhulawa (Fenty U Puluhulawa, 2011) bahwa koordinasi pada hakikatnya adalah tindakan kerja sama saling menunjang untuk mendapatkan kesalarasan.

\section{Simpulan}

Berdasarkan uraian di atas, maka dapat ditarik simpulan sebagai berikut

1. Dalam proses pendaftaran peralihan hak atas tanah di Kantor Pertanahan Kabupaten Kupang untuk pihak Pertanahan merujuk dan berpegan pada Pasal 103 (1) dengan limit tidak waktu boleh lebih dari 7 hari namun pihak Pertanahan sendiri juga tidak bisa menolak setiap pendaftaran peralihan hak atas tanah yang melebihi limit waktu 7 hari karena PPAT selalu menggunakan dasar hukum Pasal 103 ayat (7).

2. Impilkasi hukum yang timbul dari inkonsistensi dari Pasal 103 ayat (1) dengan ayat (7) menimbulkan tidak adanya kepastian hukum bagi pihak Pertanahan dalam memproses pendaftaran peralihan ha katas tanah di Kantor Pertanahan Kabupaten Kupang.

\section{DAFTAR PUSTAKA}

\section{Buku-Buku}

Kountur Ronny, 2003, Metode Penelitian Untuk Penulisan Skripsi dan Tesis, PPM, Jakarta

Urip Santoso, 2010, Pendaftaran Dan Peralihan Hak Atas Tanah, Kencana Prenada Media Group, Jakarta

\section{Jurnal}

A.Sukris Samardi, Membebaskan Positifisme Hukum Ke Ranah Hukum Progresif (Studi Pembacaan Teks Hukum Bagi Penegak Hukum), Jurnal Dinamika Hukum, Vol 12, No. 2 Mei 2012

Darwin Ginting, Reformasi Hukum Tanah dalam Rangka Perlindungan Hak Atas Tanah Perorangan dan Penanam Modal dalam Bidang Agrobisnis, Jurnal 
Hukum NO. 1 VOL. 18 JANUARI 2011: $63-82$

Fance M. Watu, Mewujudkan Kepastian Hukum, Keadilan dan Kemanfaatan Dalam Putusan Hakim Di peradilan Perdata, Jurnal Dinamika Hukum, Vol.1 2 No. 3 September 2012

Fenty U Puluhulawa, Pengawasan Sebagai Instrumen Penegakan Hukum Pada Pengelolaan Usaha Pertambangan Mineral dan Batu Bara, Jurnal Dinamika Hukum, Vol. 11 No. 2 Mei 2011

Hwian Christianto, Penafsiran Hukum Progresif Dalam Perkara Pidana, Jurnal Mimbar Hukum, Volume 23, Nomor 3, Oktober 2011

Winahyu Erwiningsih, Pelaksanaan Pengaturan Hak Menguasai Negara atas Tanah Menurut UUD 1945, Jurnal Hukum NO. Edisi Khusus VOL. 16 Oktober 2009 : 118-136, Fakultas Hukum Universitas Islam Indonesia Yogyakarta

\section{Peraturan Perundang-Undangan}

Peraturan Menteri Negara Agraria/ Kepala Badan Pertanahan Nasional Nomor 3 Tahun 1997 tentang Ketentuan Pelaksanaan Peraturan Pemerintah Nomor 24 Tahun 1997 tentang Pendaftaran Tanah 